\title{
Recent advances in the tandem annulation of 1,3-enynes to functionalized pyridine and pyrrole derivatives
}

\author{
Yi Liu ${ }^{1}$, Puying Luo ${ }^{*}$, Yang Fu ${ }^{*}$, Tianxin $\mathrm{Hao}^{1}$, Xuan Liu ${ }^{1}$, Qiuping Ding1 \\ and Yiyuan Peng 1
}

\author{
Review \\ Address: \\ ${ }^{1}$ Key Laboratory for Green Chemistry of Jiangxi Province, Key \\ Laboratory of Functional Small Organic Molecules, Ministry of \\ Education, Jiangxi Normal University, 99 Ziyang Road, Nanchang \\ 330022, China and 2Department of Gynaecology, Jiangxi Provincial \\ People's Hospital Affiliated to Nanchang University, 92 Aiguo Road, \\ Nanchang, Jiangxi, 330006, China \\ Email: \\ Puying Luo* - luopuying1979@126.com; Yang Fu* - \\ yangfu@jxnu.edu.cn \\ * Corresponding author \\ Keywords: \\ 1,3-enyne; functionalization; pyridine; pyrrole; tandem annulation
}

\author{
Beilstein J. Org. Chem. 2021, 17, 2462-2476. \\ https://doi.org/10.3762/bjoc.17.163 \\ Received: 10 August 2021 \\ Accepted: 11 September 2021 \\ Published: 22 September 2021 \\ Associate Editor: I. Baxendale \\ (C) 2021 Liu et al.; licensee Beilstein-Institut. \\ License and terms: see end of document.
}

\begin{abstract}
Great progress has been made in the tandem annulation of enynes in the past few years. This review only presents the corresponding reactions of 1,3-enyne structural motifs to provide the functionalized pyridine and pyrrole derivatives. The functionalization reactions cover iodination, bromination, trifluoromethylation, azidation, carbonylation, arylation, alkylation, selenylation, sulfenylation, amidation, esterification, and hydroxylation. We also briefly introduce the applications of the products and the reaction mechanisms for the synthesis of corresponding N-heterocycles.
\end{abstract}

\section{Introduction}

The pyridine moiety is an important class of six-membered $\mathrm{N}$-heterocycles that is widely found in many natural products, pharmaceuticals, and bioactive molecules. For instance, some pyridine derivatives have been used for therapy of HIV, cancer, inflammation, microbial infection and so on [1-5]. In addition, it is also an important synthetic unit, which is frequently used as catalyst or ligand in organic chemistry [6-10]. Therefore, the development of efficient methods for the synthesis of pyridine derivatives has attracted considerable attention [11-14]. The industrial synthetic methods of pyridines mainly involve: i) extraction from coal tar; ii) condensation of ammonia, formaldehyde, and acetaldehyde; and iii) preparation from furfural and ammonia. In addition, Hantzsch pyridine synthesis from ethyl acetoacetate, formaldehyde, and ammonia is a commonly used laboratory synthetic method. Recently, extensive and efficient methods for the construction of pyridine derivatives have been 
developed through the intramolecular or intermolecular tandem addition annulation/functionalization of alkynes with some $\mathrm{N}$-containing compounds, such as nitriles, oximes, and imines [15-19].

The pyrrole structural motif is also an invaluable five-membered N-heterocycle that is widely used in pharmaceuticals, photoelectric materials, and functional materials [20-23]. Many pyrrole derivatives play a significant role in the life science and medicine domains due to the good bioactivities, such as antitumor, anti-HIV, and anti-HSV-1 activity [24-29]. In industry, pyrrole mainly comes from the extraction of coal tar, the condensation reaction of furan and ammonia under high temperature, or the cascade cyclization reaction of acetylene, formaldehyde, and ammonia. In the laboratory, there are many efficient methods for the synthesis of pyrrole derivatives: i) Knorr reaction: the condensation of $\alpha$-aminoketones or $\alpha$-amino esters in the presence of zinc powder and sodium acetate; ii) Paal-Knorr reaction: the condensation of 1,4-dicarbonyl compounds and amines, catalyzed by formic acid in anhydrous alcohol; iii) Hantzsch reaction: the condensation of $\alpha$-halogenated carbonyl compounds, $\beta$-dicarbonyl compounds and amines; and iv) the latest developed multicomponent tandem reactions and transition metal-catalyzed coupling reactions [30-39].

Recently, substantial achievements have been made using azides as a powerful nitrogen source for the synthesis of various $\mathrm{N}$-heterocycles, such as isoquinolines, quinolines, pyridines, pyrroles, indoles, azoles, and azepines [40-45]. 1,3-Enyne, as a powerful Michael acceptor, is a wonderful synthon for the syn- thesis of N-heterocycles via tandem addition and annulation. Recently, there have been several elegant reviews covering the 1,3-enynes chemistry [46-48]. For instance, Procter and co-workers reviewed the copper-catalyzed functionalization of enynes [46]. In 2020, the Wang group reviewed the development of 2-activated 1,3-enyne in enantioselective synthesis [47]. Further, the Liu group reviewed the synthesis of allenes via transition metal-catalyzed 1,4-functionalizations of unactivated 1,3-enynes [48]. In this review, we will highlight the recent advances in the tandem annulation reactions of 1,3-enyne structural motifs for the construction of functionalized pyridines and pyrroles.

\section{Review \\ Synthesis of pyridines via tandem annulation of 1,3-enynes}

In 2015, Reddy and co-workers reported the synthesis of substituted pyridines via Lewis acid-mediated aza-annulation of 2-en4-ynyl azides 1 (Scheme 1) [49]. They discovered that Ag-mediated intramolecular annulation of 2-en-4-ynyl azides $\mathbf{1}$ could provide the corresponding 3,6-disubstituted pyridines $\mathbf{2}$ in $60-88 \%$ yield in the presence of TFA ( 2.0 equiv). The reaction substrates, 2-en-4-ynyl azides 1, derived from MBH acetates of acetylenic aldehydes, could tolerate various substituted aryl, indolyl, and alkyl (such as $n$-propyl and $n$-hexyl) groups under the standard conditions. 2-En-4-ynyl azides 1 bearing electrondonating substituents (such as methyl and methoxy groups) obviously worked better than those with electron-withdrawing (such as nitro, cyano, acetyl, and trifluoromethyl) groups.
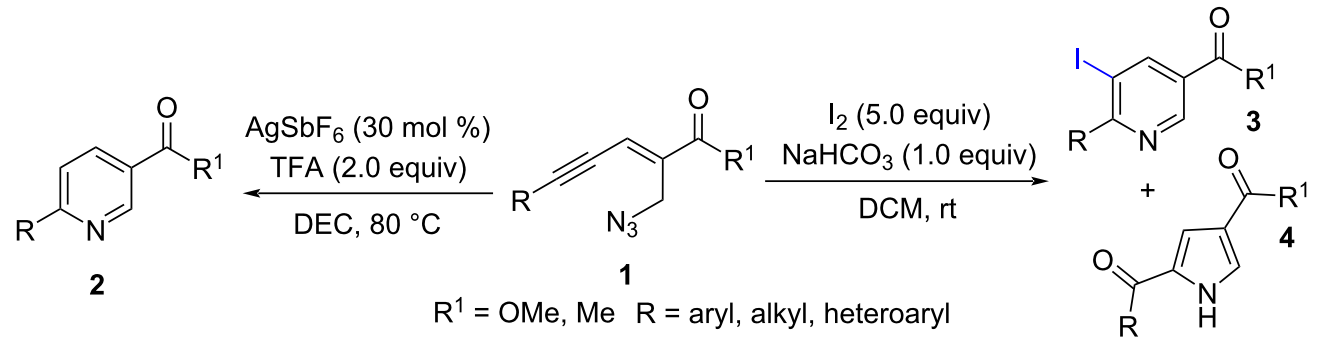

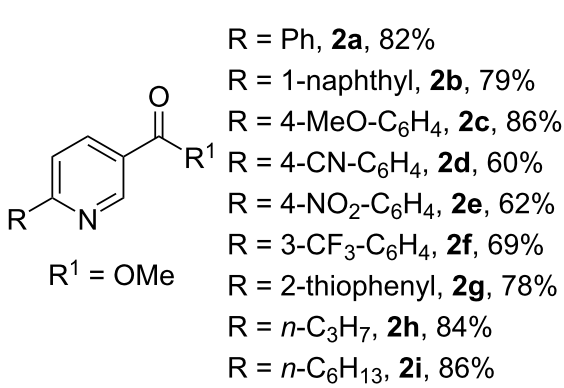

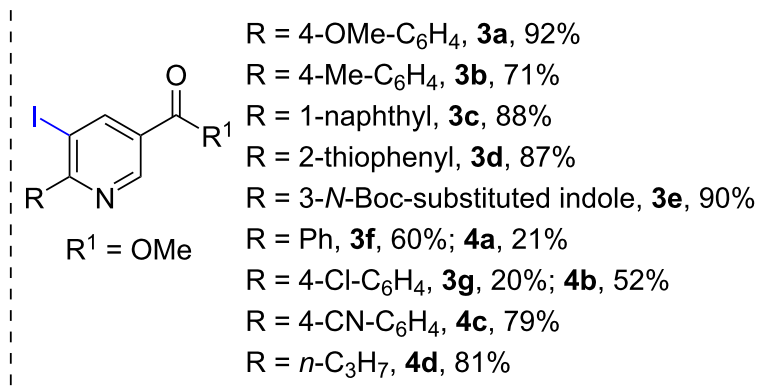


Meanwhile, they also found that the aza-annulation could be carried out under iodine-mediated electrophilic annulation reaction conditions to give 5-iodo-3,6-disubstituted pyridines $\mathbf{3}$ as the major products, occasionally with a small amount of 2-acylated pyrroles 4 .

The proposed mechanism for the Ag-catalyzed aza-annulation of (E)-2-en-4-ynyl azides 1 was considered to involve 6-endodig cyclization to give a corresponding $N$ - $\mathrm{N}_{2}$-substituted 1,2dihydropyridine silver salt $\mathbf{5}$. This was protonated by TFA and the following species neutralized by base to provide a final 3,6disubstituted pyridine product 2 (Scheme 2). However, an iodonium ion $\mathbf{6}$ was formed as a key intermediate in $\mathrm{I}_{2}$-mediated aza-annulations. Subsequently, the iodonium ion 6 proceeds through a 6-endo-dig cyclization to form the 5-iodopyridine $\mathbf{3}$
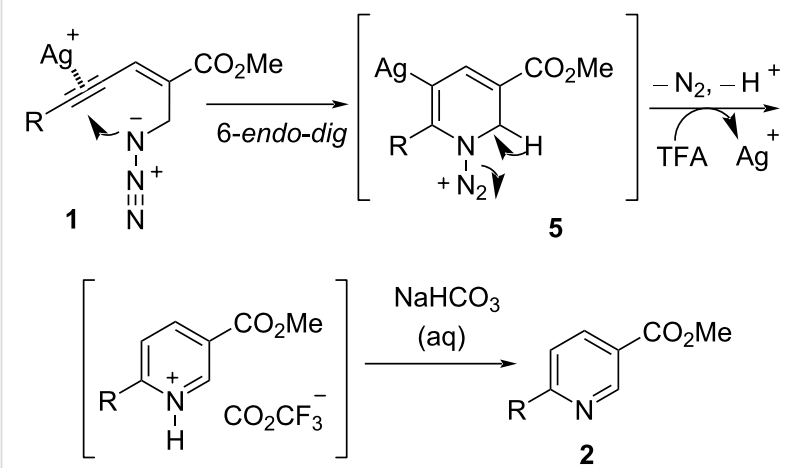

Scheme 2: The proposed mechanism of Ag-catalyzed aza-annulation.
On the other side, the iodonium ion 6 may undergo 5-exo-dig cyclization to yield the 2-acylpyrrole 4. Normally, $(E)$-2-en-4yn-1-azides 1 with electron-rich substituent groups favorably give the 5-iodopyridine $\mathbf{3}$, while for substrates containing electron-poor groups, the 2-acylpyrrole $\mathbf{4}$ is favored (Scheme 3).

Then, the Reddy group developed a copper-catalyzed aminative aza-annulation of enynyl azides with $\mathrm{N}$-fluorobenzenesulfonimide (NFSI) to provide amino-substituted nicotinate derivatives 8 in good to excellent yield (Scheme 4) [50]. The investigation showed that the electronic effect of the residue $\mathrm{R}$ on the substrates influences the results significantly. (E)-2-en-4-ynyl azides 1 bearing electron-donating groups had better reactivity, with a higher yield and a shorter reaction time. In addition, substrates 1 with aliphatic groups (such as $\mathrm{R}=n$-propyl, $n$-pentyl, and $n$-hexyl) were also tolerated under standard conditions, with an excellent yield.

The previous literature and control experiments showed that this aminative aza-annulation reaction may undergo a free-radical addition pathway. Firstly, NFSI oxidizes $\mathrm{Cu}(\mathrm{I})$ to form bissulfonylamidyl radical 10. Secondly, intermolecular nitrogen freeradical addition to the alkyne provides the vinyl radical $\mathbf{1 1}$. Then, there may be two possible pathways. Path a: vinyl radical 11 is trapped by $\mathrm{Cu}(\mathrm{II})$ to deliver the $\mathrm{Cu}$ (III) species $\mathbf{1 2}$, which undergoes intramolecular annulation and reductive elimination to afford the desired product 8 and regenerate the $\mathrm{Cu}(\mathrm{I})$ catalyst. Path b: vinyl radical intermediate $\mathbf{1 1}$ is oxidized by $\mathrm{Cu}(\mathrm{II})$ to give the cationic vinyl species 14. Finally, the intramolecular

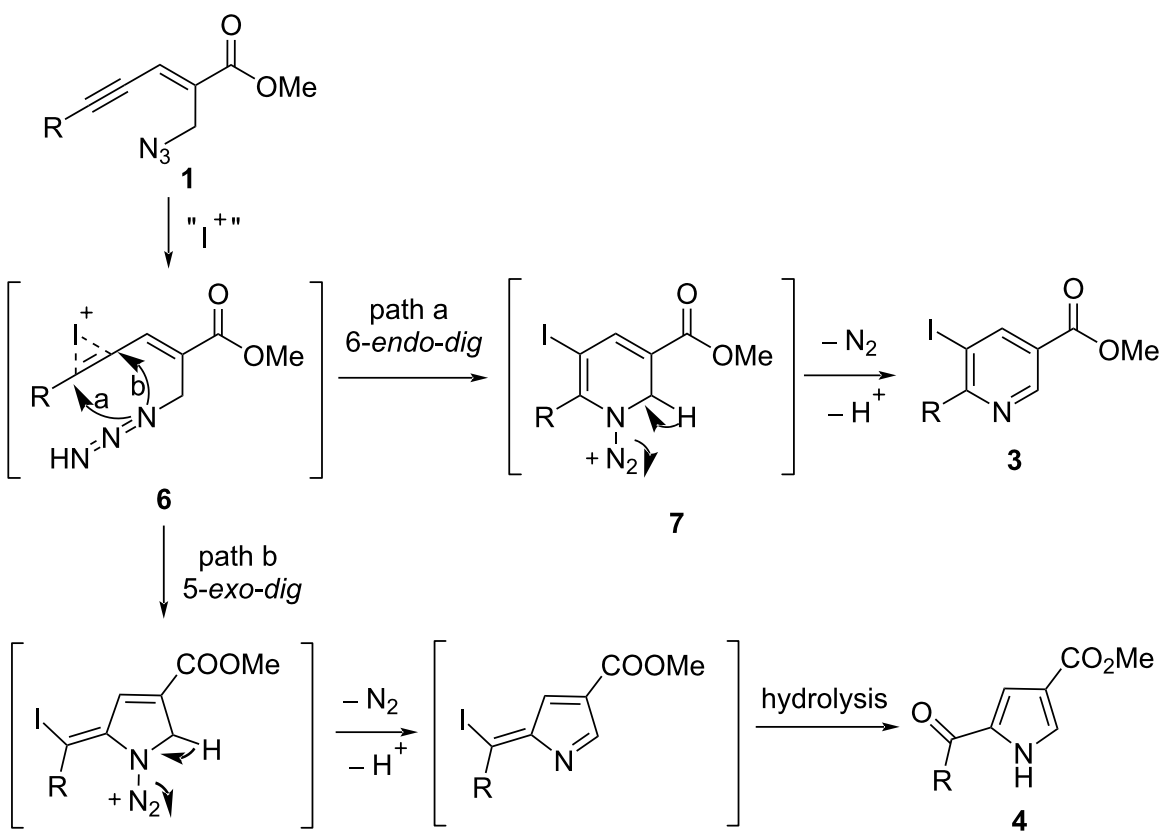




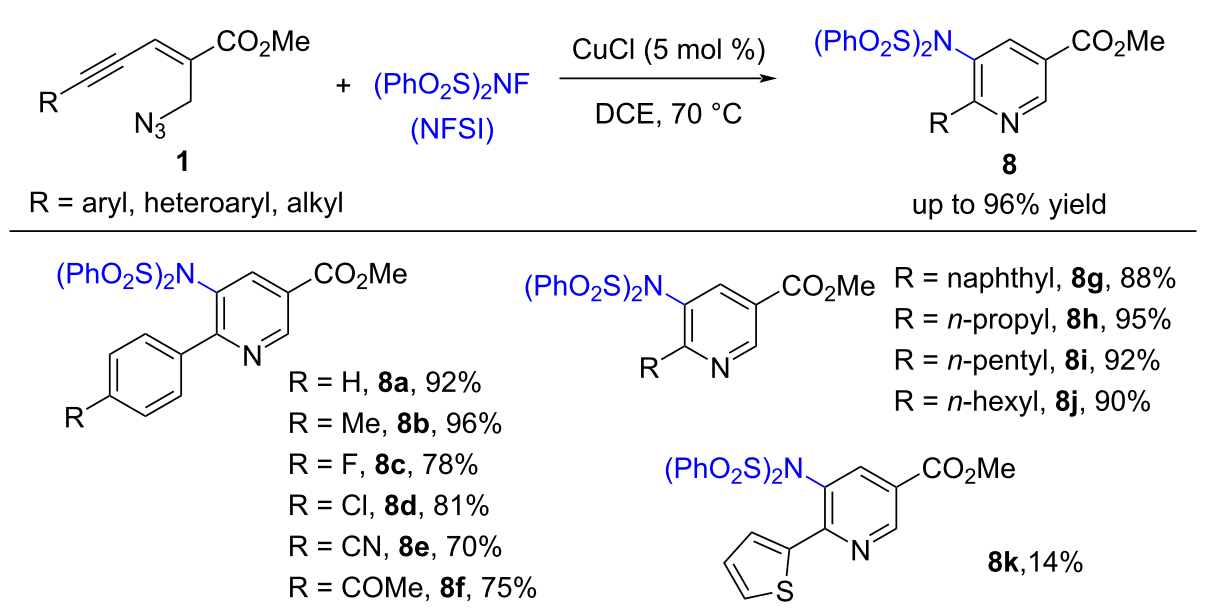

Scheme 4: Copper-catalyzed amination of $(E)$-2-en-4-ynyl azides 1.

nucleophilic attack by azide and the following deprotonation by a fluoride anion provide the final product $\mathbf{8}$ (Scheme 5).

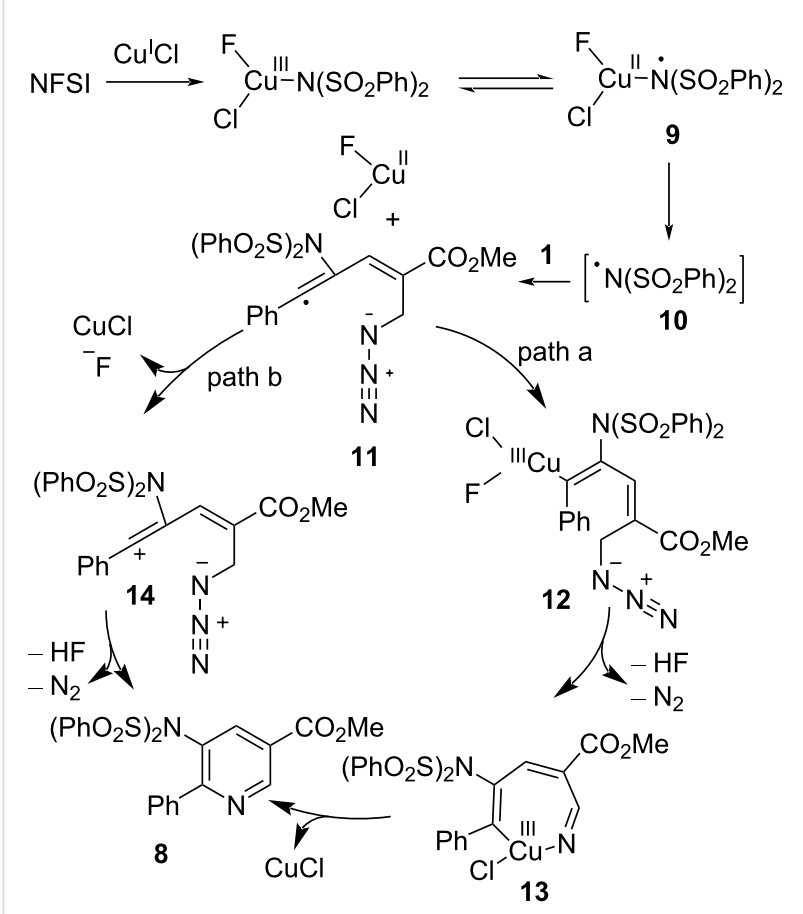

Scheme 5: The proposed mechanism of copper-catalyzed amination.

The derivatization of sulfonated aminonicotinates $\mathbf{8}$ could easily be achieved. Desulfonylation of aminonicotinate $\mathbf{8 b}$ proceeded smoothly in the presence of triflic acid (2.0 equiv) in DCE at $90{ }^{\circ} \mathrm{C}$ to provide the desulfonated 5-amino-substituted nicotinate 15 in 77\% yield. Furthermore, treatment of aminonicotinate $\mathbf{8 b}$ with $\mathrm{KOH}$ (8.0 equiv) in $\mathrm{MeOH}$, or with $\mathrm{NiCl}_{2}$ (dppp) (5 mol \%) and $\mathrm{K}_{3} \mathrm{PO}_{4}$ (4.0 equiv) in 1,4-dioxane afforded 5-(phenylsulfonamido)-6-( $p$-tolyl)nicotinic acid 16 (in 90\% yield) and monodesulfonated nicotinate 17 (in 70\% yield), respectively (Scheme 6).

Selenyl- and sulfenylpyridine derivatives are gaining prominence due to the prospective biological activities. They could be used for treatment of HIV, cancer, inflammation, and microbial infection. Therefore, the synthesis of selenyl- and sulfenylpyridines has attracted considerable attention. In 2019, the Reddy group reported a copper-catalyzed aza-annulation of enynyl azides 1 for the synthesis of 5-selenyl- and sulfenylpyridine derivatives 18 and 19 (Scheme 7) [51]. Diorganyl dichalcogenides $\left(\mathrm{R}^{1} \mathrm{XXR}^{1}, \mathrm{X}=\mathrm{Se}, \mathrm{S}\right)$ were used as selenyl and sulfenyl sources, respectively. The method was performed under open atmosphere to provide the target products in good to excellent yield. In comparison, the selenoamination of $(E)$-2-en4-ynyl azides 1 showed higher reactivity and could be carried out at $0{ }^{\circ} \mathrm{C}$ in $1 \mathrm{~h}$ to give the selenyl-substituted nicotinates $\mathbf{1 8}$ in excellent yield. Electron-donating and electron-withdrawing group-substituted diaryl diselenides, 1,2-di(thiophen-2-yl)diselane, and dimethyl diselenide were compatible to give the corresponding products 18. The sulfenylamination of $(E)-2$-en-4ynyl azides 1 could also be carried out at $90{ }^{\circ} \mathrm{C}$ in $8 \mathrm{~h}$ to provide the 5-sulfenyl-substituted nicotinates 19 efficiently.

Based on previous literature and control experiments, the possible mechanism is outlined in Scheme 8. First, the $\mathrm{Cu}$-complex-polarized $\mathrm{X}-\mathrm{X}$ bond can promote the electrophilic addition onto the alkyne to generate intermediate 20. Then, the intramolecular nucleophilic attack by azide and the following deprotonation give the final product $\mathbf{1 8}$ or $\mathbf{1 9}$, respectively.

5-Selenyl- and 5-sulfenyl-substituted nicotinates can carry out versatile transformations, which have potential application in 


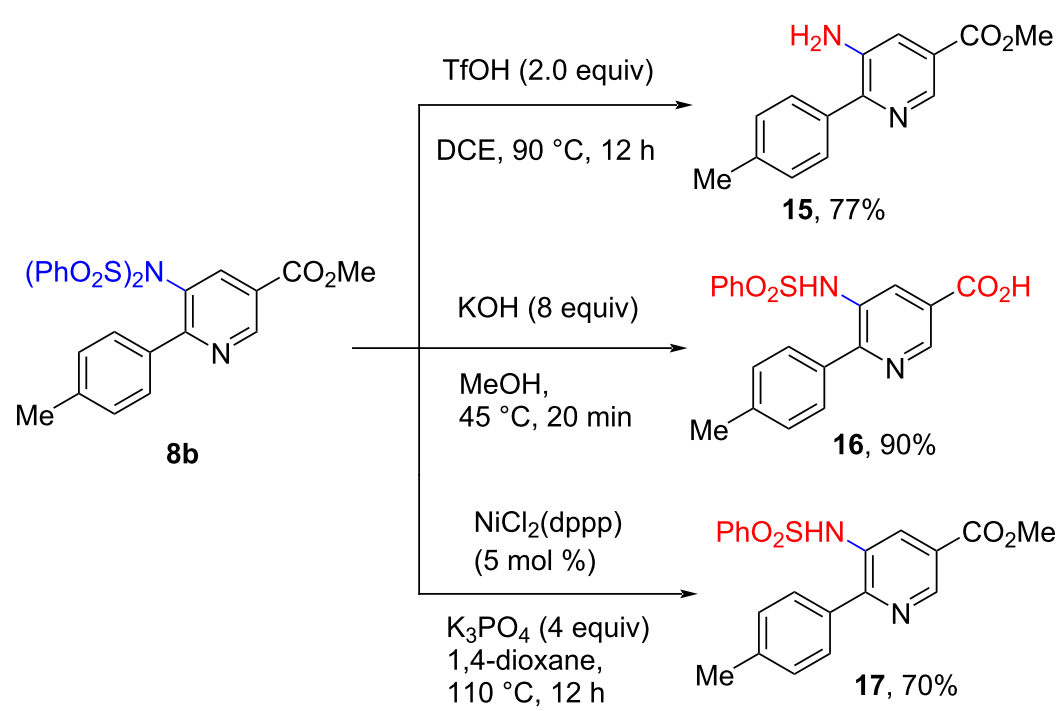

Scheme 6: The derivatization of sulfonated aminonicotinates.<smiles>[R]C#CC=C(CN)C(=O)OC</smiles>

$\mathrm{R}=$ aryl, heteroaryl

$\mathrm{R}^{1} \mathrm{XXR}^{1}$ (0.7 equiv)

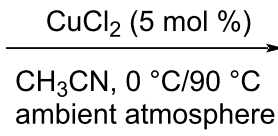

1
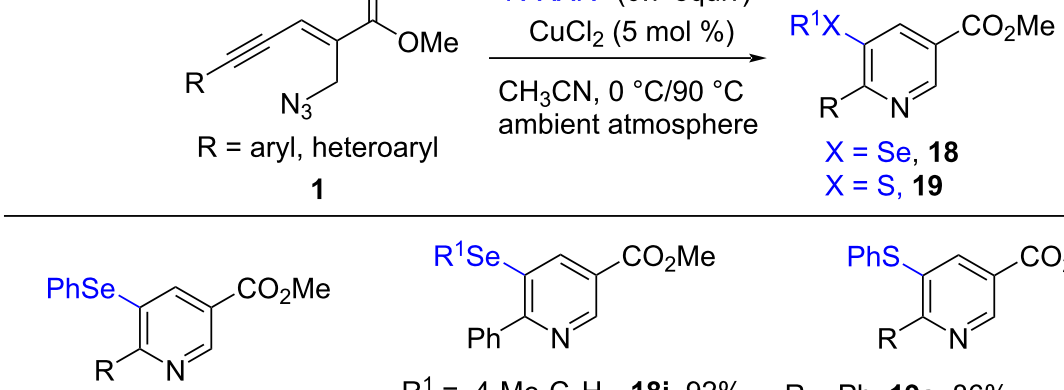

$\mathrm{R}=\mathrm{Ph}, 18 \mathrm{a}, 98 \%$

$\mathrm{R}=4-\mathrm{MeO}-\mathrm{C}_{6} \mathrm{H}_{4}, \mathbf{1 8 b}, 96 \%$

$\mathrm{R}=4-\mathrm{Me}-\mathrm{C}_{6} \mathrm{H}_{4}, 18 \mathrm{c}, 95 \%$

$\mathrm{R}=3,5-\mathrm{diMe}-\mathrm{C}_{6} \mathrm{H}_{3}, \mathbf{1 8 d}, 97 \%$

$\mathrm{R}=4-\mathrm{Cl}-\mathrm{C}_{6} \mathrm{H}_{4}, 18 \mathrm{e}, 93 \%$

$\mathrm{R}=4-\mathrm{F}-\mathrm{C}_{6} \mathrm{H}_{4}, 18 \mathrm{f}, 89 \%$

$\mathrm{R}=$ naphthyl, $\mathbf{1 8 g}, 93 \%$

$\mathrm{R}=2$-thienyl, 18h, $78 \%$

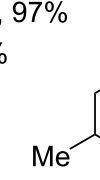

$\mathrm{R}^{1}=3-\mathrm{F}-\mathrm{Ph}, 19 \mathrm{i}, 77 \%$

$\mathrm{R}^{1}=4-\mathrm{Me}-\mathrm{Ph}, 19 \mathrm{j}, 90 \%$<smiles>[R]c1ncc(C(C)=O)cc1Sc1ccccc1</smiles>

$\mathrm{R}=\mathrm{Ph}, 19 \mathrm{a}, 86 \%$

$\mathrm{R}=4-\mathrm{MeO}-\mathrm{C}_{6} \mathrm{H}_{4}, 19 \mathrm{~b}, 95 \%$

$\mathrm{R}=4-\mathrm{Me}-\mathrm{C}_{6} \mathrm{H}_{4}, 19 \mathrm{c}, 90 \%$

$\mathrm{R}=3,5-\mathrm{diMe}-\mathrm{C}_{6} \mathrm{H}_{3}, 19 \mathrm{~d}, 93 \%$

$\mathrm{R}=4-\mathrm{Cl}-\mathrm{C}_{6} \mathrm{H}_{4}, 19 \mathrm{e}, 82 \%$

$\mathrm{R}=4-\mathrm{F}-\mathrm{C}_{6} \mathrm{H}_{4}, \mathbf{1 9 f}, 79 \%$

$\mathrm{R}=$ naphthyl, 19g, 74\%

$\mathrm{R}=$ 2-thienyl, $19 \mathrm{~h}, 70 \%$

Scheme 7: Copper-catalyzed chalcogenoamination of (E)-2-en-4-ynyl azides 1.

pharmaceutical, agrochemical, and organic synthetic chemistry. For example, 5-selenyl- and 5-sulfenyl-appended nicotinates $18 \mathrm{c}$ and 19c could be oxidized by mCPBA to the corresponding selenoxide, sulfoxide, and sulfone derivatives $\mathbf{2 2}, \mathbf{2 4}$, and $\mathbf{2 5}$, respectively. In addition, 5-selenyl-substituted nicotinate 18c could be converted to the corresponding acid 23 in $94 \%$ yield in the presence of $\mathrm{KOH}$ (2.0 equiv) in $\mathrm{MeOH}$ (Scheme 9).
In 2011, Lee and co-workers reported a one-pot method for the construction of polysubstituted pyridines 29 via tandem sequential reactions of nitriles $\mathbf{2 6}$, Reformatsky reagents $\mathbf{2 7}$, and 1,3enynes 28 (Scheme 10) [52]. The tandem reaction involved a regio- and chemoselective addition of the Blaise reaction intermediate to 1,3-enyne, and the following sequential processes: isomerization, cyclization, and aromatization. Both carbocyclic 


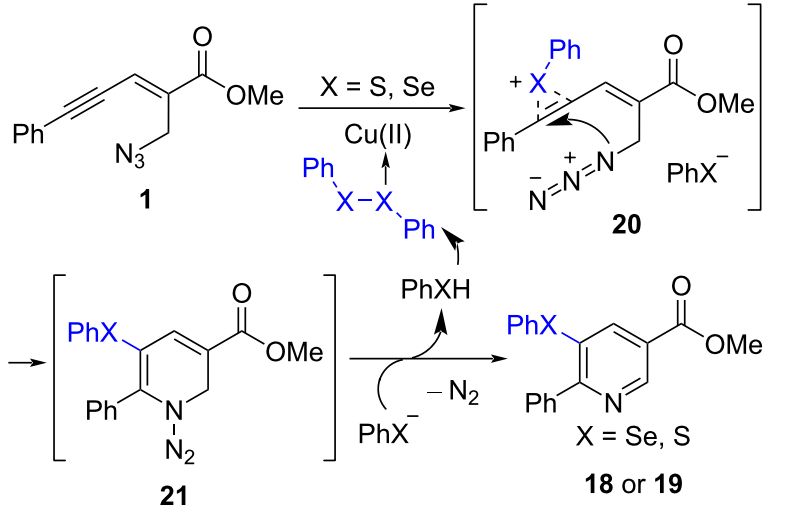

Scheme 8: The possible mechanism of chalcogenoamination. and acyclic 1,3-enyenes $\mathbf{2 8}$ were compatible to give the corresponding esterified pyridines $\mathbf{2 9}$ in moderate to high yield. It is worth noting that 1,3-enynes $\mathbf{2 8}$ bearing internal alkyne moieties were not tolerated as substrates.

In 2016, Aïssa and co-workers reported a nickel-catalyzed [4 + 2]-cycloaddition of 3-azetidinones $\mathbf{3 0}$ with 1,3-enynes $\mathbf{3 1}$ for the synthesis of 3-hydroxy-4,5-alkyl-substituted pyridines 33 (Scheme 11) [53]. The transformation involved a two-step sequence of successive reactions: Firstly, the nickel-catalyzed [4 +2]-cycloaddition of 1,3-enynes $\mathbf{3 1}$ and $N$-Ts-substituted 3 -azetidinone $\mathbf{3 0}$ afforded dihydropyridinones $\mathbf{3 2}$ in good yield. The next step involved the hydrogenation of dihydropyridinones $\mathbf{3 2}$ and a following desulfonylation and aromatization to give pyridine derivatives $\mathbf{3 3}$ in moderate to good yield.

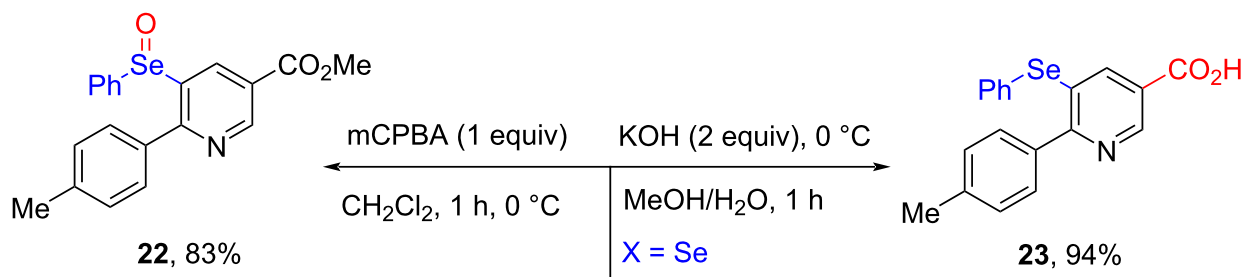

$22,83 \%$
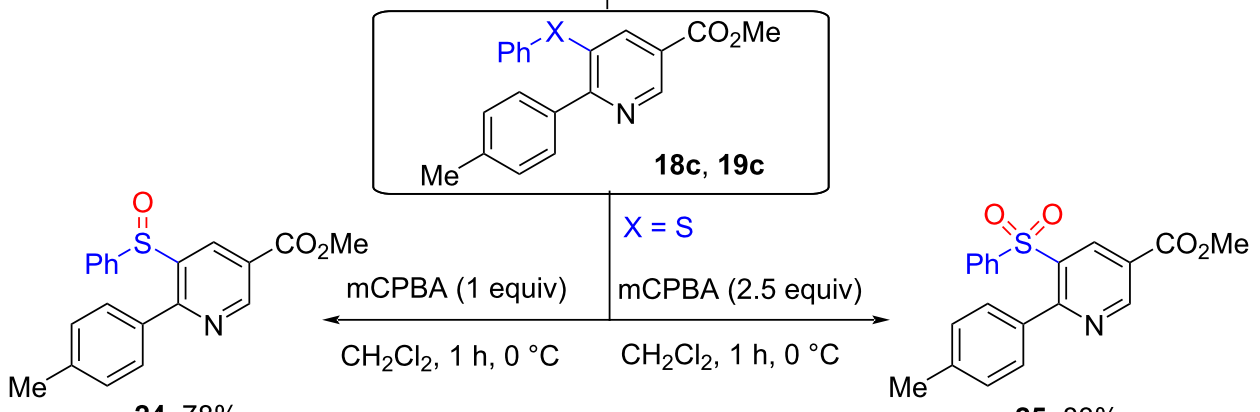

$24,78 \%$

$25,83 \%$

Scheme 9: The derivatization of 5-selenyl- and 5-sulfenyl-substituted nicotinates.

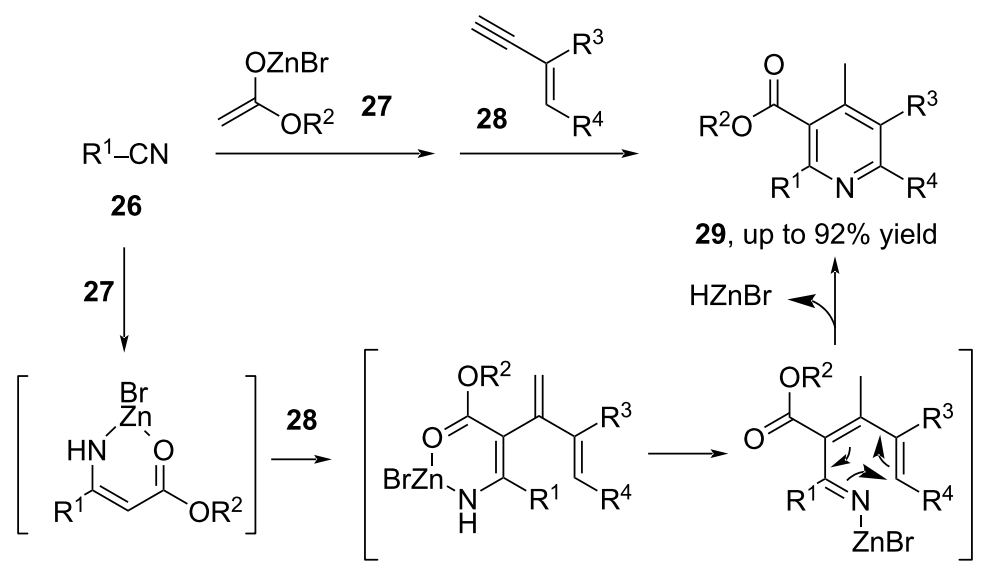

Scheme 10: The tandem reaction of nitriles, Reformatsky reagents, and 1,3-enynes. 


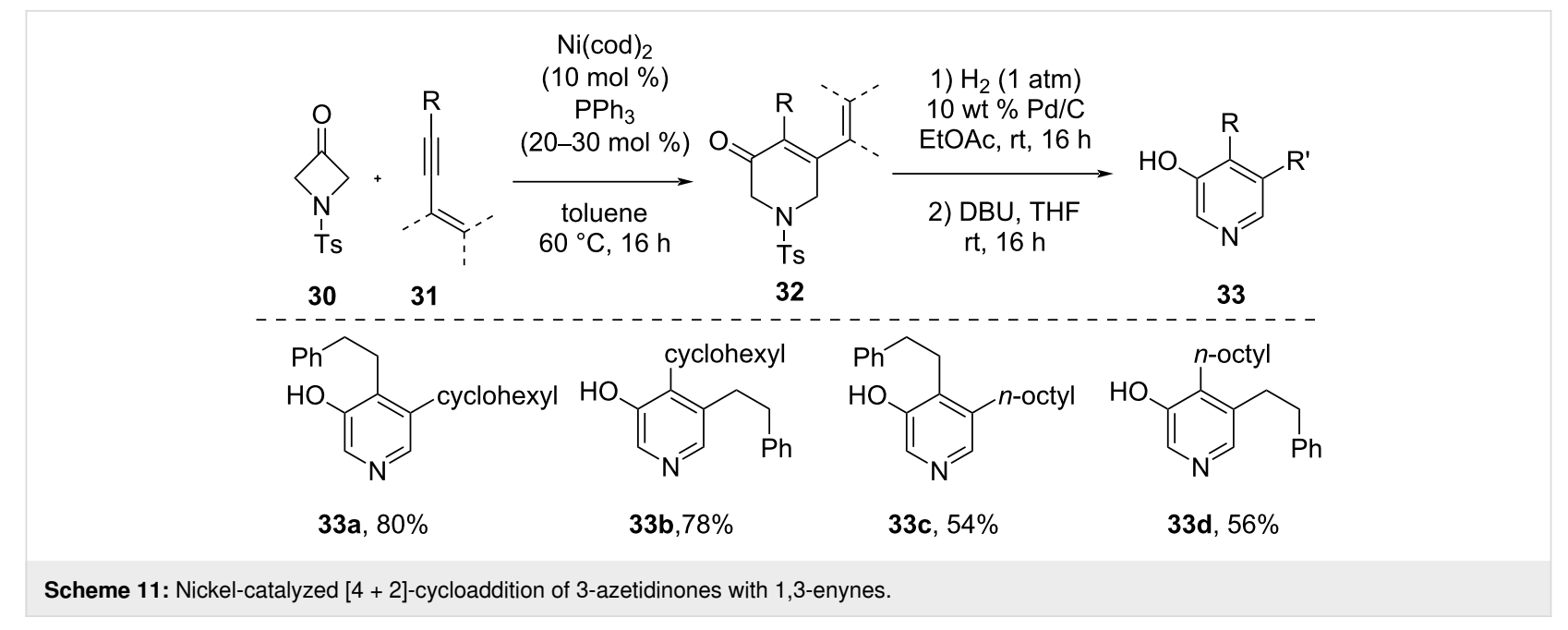

\section{Synthesis of pyrroles via tandem annulation of 1,3-enynes}

Recently, great achievements have been made in electrophilic iodocyclization of alkynes for the synthesis of five- or six-membered cyclic compounds [54]. Various efficient synthetic methods have been developed for the synthesis of halogenated pyrroles, which are widely presented in many pharmacologically active natural products, bioactive molecules, and organic building blocks. Based on the previous studies on heterocycle synthesis, Punniyamurthy and co-workers designed the electrophilic iodocyclization of 2-nitro-1,3-enynes $\mathbf{3 4}$ for the synthesis of pyrrole derivatives. In 2013, they reported an efficient route to pentasubstituted pyrroles from 2-nitro-1,3-enynes 34, amines, and iodine under mild conditions (Scheme 12) [55]. The reaction was performed in $\mathrm{CH}_{2} \mathrm{Cl}_{2}$ at ambient conditions in the presence of 2.0 equiv of $\mathrm{K}_{2} \mathrm{CO}_{3}$. Substrates bearing electrondonating or electron-withdrawing groups were compatible under standard conditions to give the highly substituted pyrroles<smiles>[R]C#CC(=C[R])[N+](=O)[O-]</smiles>
base $\downarrow^{34} \mathrm{R}^{3} \mathrm{NH}_{2}$

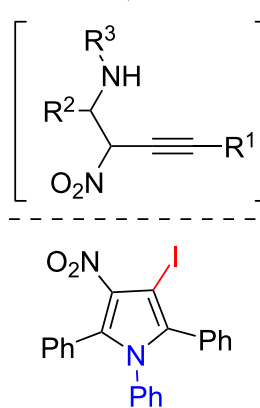

$35 a, 82 \%$<smiles>O=[N+]([O-])c1c(I)c(-c2ccccc2)n(Cc2ccccc2)c1-c1ccccc1</smiles>

35d, $33 \%$

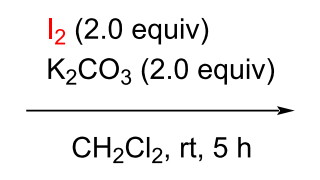<smiles>[R]c1c(I)c([N+](=O)[O-])c([R])n1[R]</smiles>

35

[O]

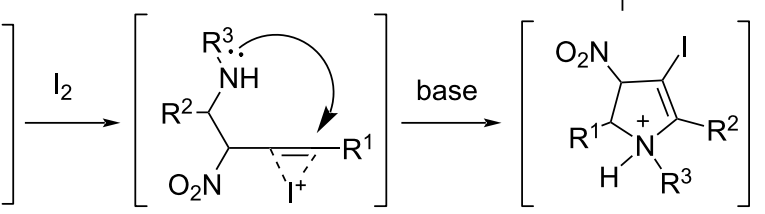

$\left.\left.\mathrm{O}_{2} \mathrm{~N} \quad \mathrm{I}^{\prime}{ }^{\prime} \mathrm{R}\right] \mathrm{H}^{\prime} \mathrm{R}^{3}\right]$<smiles>COc1ccc(-c2c(I)c([N+](=O)[O-])c(-c3ccccc3)n2-c2ccccc2)cc1</smiles>

$35 b, 68 \%$<smiles>CCCCn1c(-c2ccccc2)c(I)c([N+](=O)[O-])c1-c1ccccc1</smiles>

$35 \mathbf{e}, 30 \%$<smiles>O=[N+]([O-])c1c(I)c(-c2ccccc2)n(-c2ccccc2)c1-c1ccc(F)cc1</smiles>

$35 c, 56 \%$<smiles>O=[N+]([O-])c1c(I)c(-c2ccccc2)n(-c2ccccc2)c1COBr</smiles>

35f, n.d. 
in moderate to good yield. Aliphatic amines were also tolerated, providing the desired products in only moderate yield. The plausible mechanism involves a tandem base-promoted azaMichael addition, 1,2-iodocyclization, and iodine-mediated oxidative aromatization.

In 2017, Zhang and co-workers reported a silver-catalyzed tandem reaction of 2-trifluoromethyl-1,3-enynes 36 with primary amines, affording various trifluoromethyl-substituted 3-pyrrolines [56]. Subsequently, they also developed a novel route for the synthesis of halogenated trifluoromethylated pyrroles $\mathbf{3 7}$ and $\mathbf{3 8}$ by sequential intermolecular hydroamination reaction of 2-trifluoromethyl-1,3-enynes 36 with aliphatic primary amines and the following NXS-mediated oxidative cyclization (Scheme 13) [57]. The method tolerated various substituted benzylamines, 2-phenylethanamines, isopropylamine, and other aliphatic chain-like amines. Furthermore, both furan-2-ylmethanamine and thiophen-2-ylmethanamine were reacted smoothly with NIS under standard conditions, while they did not react well with NBS. Notably, under the same reaction conditions, the desired products of the iodination and bromoniation reactions were trifluoromethylated monoiodopyrroles $\mathbf{3 7}$ and dibromopyrroles $\mathbf{3 8}$, respectively.
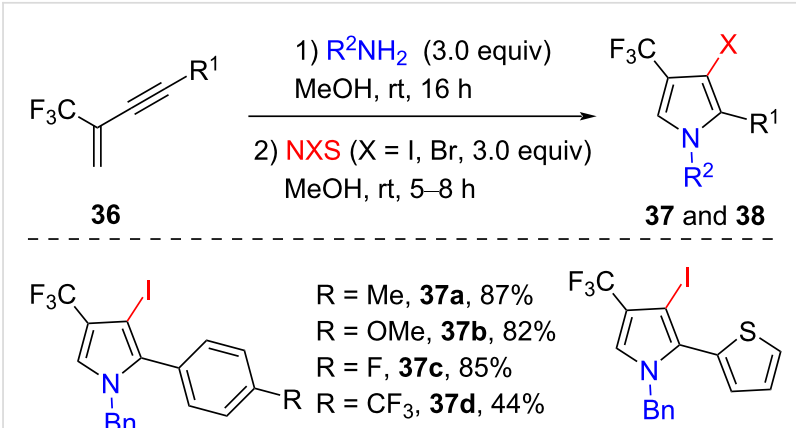

$\mathrm{R}=\mathrm{Me}, 37 \mathrm{a}, 87 \% \quad \mathrm{~F}_{3} \mathrm{C}$

$\mathrm{R}=\mathrm{OMe}, \mathbf{3 7 b}, 82 \%$

$\mathrm{R}=\mathrm{F}, 37 \mathrm{c}, 85 \%$

$\mathrm{R}=\mathrm{CF}_{3}, 37 \mathrm{~d}, 44 \%$ 37 and 38<smiles>[R]c1cccc(Cn2c(Br)c(C(F)(F)F)c(Br)c2-c2ccccc2)c1</smiles>

$\mathrm{R}=4-\mathrm{Me}, 38 \mathrm{a}, 65 \%$ $\mathrm{R}=4-\mathrm{OMe}, 38 \mathrm{~b}, 67 \%$

$\mathrm{R}=4-\mathrm{F}, 38 \mathrm{c}, 78 \%$

$\mathrm{R}=4-\mathrm{CF}_{3}, \mathbf{3 8 d}, 77 \%$

$\mathrm{R}=4-\mathrm{Br}, 38 \mathrm{e}, 70 \%$

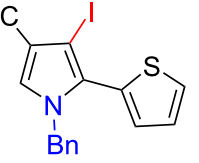

37e, $61 \%$<smiles>CC(c1ccccc1)n1c(Br)c(Br)c(C(F)(F)F)c1-c1ccccc1</smiles>

$38 f, 60 \%$

Scheme 13: Electrophilic halogenation of 2-trifluoromethyl-1,3-enynes to pyrroles.

Subsequently, Punniyamurthy and co-workers also described the copper-catalyzed cascade cyclization of 2-nitro-1,3-enynes 34 to tetrasubstituted pyrroles 39 (Scheme 14) [58]. Through<smiles>[R]C#C/C(=C\[R])[N+](=O)[O-]</smiles>

34<smiles>[R19]CCCCCCCCCCC[R19]=[O+]</smiles>

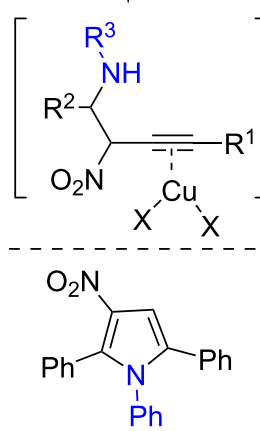

$39 a, 87 \%$<smiles>[R]n1c(-c2ccccc2)cc([N+](=O)[O-])c1-c1ccccc1</smiles>

$\mathrm{R}^{3}=4-\mathrm{MeC}_{6} \mathrm{H}_{4}, 39 \mathrm{~d}, 92 \%$

$\mathrm{R}^{3}=4-\mathrm{ClC}_{6} \mathrm{H}_{4}, 39 \mathrm{e}, 78 \%$

$\mathrm{R}^{3}=4-\mathrm{NO}_{2} \mathrm{C}_{6} \mathrm{H}_{4}, 39 \mathrm{f}, 76 \%$

$\mathrm{R}^{3}=$ 2-fluorenyl, $39 \mathrm{~g}, 53 \%$<smiles>[R]c1cc([N+](=O)[O-])c([R])n1[R]</smiles>

39

$\mathrm{HX} /[\mathrm{O}]$ $x^{\prime} x^{-}$<smiles>[R]C1=C([Al])C([N+](=O)[O-])C([R])N1[R]</smiles><smiles>O=[N+]([O-])c1cc(-c2ccccc2)n(-c2ccccc2)c1-c1ccc(F)cc1</smiles>

$39 c, 81 \%$

Scheme 14: Copper-catalyzed cascade cyclization of 2-nitro-1,3-enynes with amines. 
screening the conditions, the $\mathrm{Cu}(\mathrm{OTf})_{2}$-promoted (5 mol \%) annulation addition reaction of 2-nitro-1,3-enynes $\mathbf{3 4}$ and amines was carried out smoothly in THF at room temperature under air. The protocol showed broad substrate scope, and various different aromatic substrates $\left(\mathrm{R}^{1}, \mathrm{R}^{2}\right.$, and $\mathrm{R}^{3}=$ aryl) reacted well. However, no target product was observed when aliphatic amine was used as substrate under standard conditions. The proposed catalytic cycle included aza-Michael addition of arylamines, Lewis acid copper(II)-catalyzed intramolecular 5-endo-dig cyclization, protonation, and oxidation to provide the final products, tetrasubstituted pyrroles 39.

The introduction of a trifluoromethyl group into organic molecules can efficiently modify the physical, chemical, and biological properties of the compounds. A trifluoromethyl-substituted pyrrole unit is widely present in many natural compounds and pharmaceuticals with high biological activity. Based on our previous study on the construction of trifluoromethylated coumarins [59], we recently developed a Rh-catalyzed approach to trifluoromethyl-substituted pyrroles using the Togni reagent II as trifluoromethyl source. It involves a three-component cascade reaction of 1,3-enynes, anilines, and Togni reagent II to afford fully substituted pyrrole derivatives in DMF at room temperature (Scheme 15) [60]. The reaction was promoted by $\mathrm{Cu}(\mathrm{OAc})_{2} \cdot \mathrm{H}_{2} \mathrm{O}$ (2.0 equiv) and $\mathrm{Ca}(\mathrm{OH})_{2}$ (2.0 equiv), providing the desired products in moderate to good yield. Various substituted 1,3-enynes with methyl, methoxy, fluoro, and chloro groups could react with $p$-toluidine under standard conditions in moderate yield (40-71\%). Notably, aromatic amines bearing electron-donating or electron-withdrawing groups were compatible. When 2-naphthylamine was used under standard conditions, $\alpha$-trifluoromethyl-substituted 2-naphthylamine was obtained as major product ( $51 \%$ yield), and only a trace amount of the desired product was observed. Control experiments indicated that the possible reaction mechanism may proceed through a $\mathrm{Cu}(\mathrm{II}) / \mathrm{Rh}$ (III)-promoted radical process.

Aryl azides are versatile intermediates, which were widely used in synthetic and medicinal chemistry as well as material and biological sciences. Recently, great attention has been paid to synthesize organic azido compounds via various transformations. In 2020, we reported an efficient method for the synthesis of fully substituted azidopyrroles 41 via $\mathrm{Cu}$ - and $\mathrm{Mn}$-co-mediated aerobic oxidative cyclization/azidation reaction of 2-nitro1,3-enynes 34 with amines, and trimethylsilyl azide $\left(\mathrm{TMSN}_{3}\right.$, Scheme 16) [61]. The reaction could be carried out efficiently

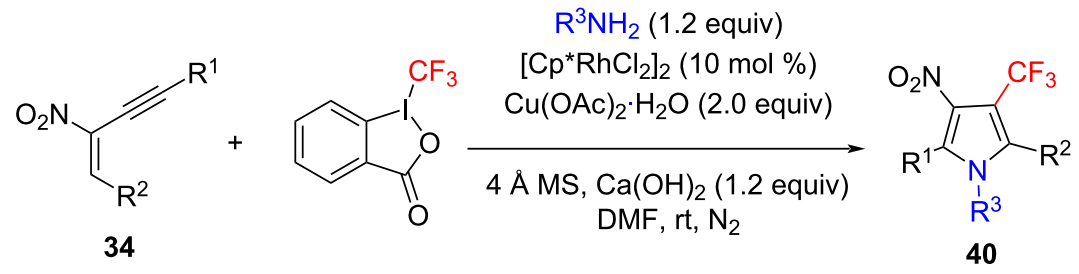<smiles>Cc1ccc(-n2c(-c3ccccc3)c(-c3ccccc3)c(C(F)(F)F)c2[N+](=O)[O-])cc1</smiles>

$40 a, 78 \%$

40d, $65 \%$<smiles>COc1ccc(-c2c(C(F)(F)F)c([N+](=O)[O-])c(-c3ccccc3)n2-c2ccc(C)cc2)cc1</smiles>

$40 \mathrm{~b}, 50 \%$<smiles>Cc1ccc(-n2c(-c3ccc(F)cc3)c([N+](=O)[O-])c(C(F)(F)F)c2-c2ccccc2)cc1</smiles>

$40 c, 45 \%$<smiles>O=[N+]([O-])c1c(C(F)(F)F)c(-c2ccccc2)n(-c2cccc(Cl)c2)c1-c1ccccc1</smiles><smiles>O=[N+]([O-])c1c(C(F)(F)F)c(-c2ccccc2)n(-c2ccc(OC(F)(F)F)cc2)c1-c1ccccc1</smiles>

$40 e, 48 \%$<smiles>CCCCc1c(C(F)(F)F)c([N+](=O)[O-])c(-c2ccccc2)n1-c1ccc(C)cc1</smiles>

40f, trace<smiles>CCCCCn1c(-c2ccccc2)c(-c2ccccc2)c([N+](=O)C(F)(F)F)c1-c1ccccc1</smiles>

$40 \mathrm{~g}$, n.d. 




in the presence of 2.0 equiv of $\mathrm{Cu}(\mathrm{OAc})_{2} \cdot \mathrm{H}_{2} \mathrm{O}$. Interestingly, the addition of $10 \mathrm{~mol} \% \mathrm{MnCl}_{2}$ could promote the reaction more smoothly. A wide range of substituted aromatic amines were reacted well, while amines substituted with strongly electron-withdrawing (such as nitro and trifluoromethyl) groups, heteroaryl amines, and aliphatic amines were not compatible. Control experiments showed that the addition of 2.0 equiv of (2,2,6,6-tetramethylpiperidin-1-yl)oxyl (TEMPO) under standard conditions could inhibit the formation of target product. In contrast, the compound TEMPO-N 3 was detected by GC-MS analysis. Based on the radical trapping experiment and previous reports, the reaction may undergo a radical process.

2-Carbonylpyrrole is a key subunit of many bioactive natural products with potential biological activities or pharmacological activities. For instance, longanlactone, zomepirac (Zomax), ketorolac and pollenopyrroside A are pyrrole derivatives bearing a 2-carbonyl group. Therefore, the synthesis of such kinds of pyrrole derivatives is highly valuable. In 2017, Baire and Gandhi reported an Ag-catalyzed cascade cyclization of 6-hydroxyhex-2-en-4-ynals $\mathbf{4 2}$ and primary amines to give the 2 - $(\alpha$-hydroxyacyl)pyrroles $\mathbf{4 3}$ in moderate to good yield (Scheme 17) [62]. The proposed mechanism involves the condensation of amine and aldehyde to give the imine $\mathbf{4 4}$ and the $\mathrm{AgNO}_{3}$-promoted 5-exo-dig cyclization of imine to form a zwitter ion intermediate $\mathbf{4 5}$.
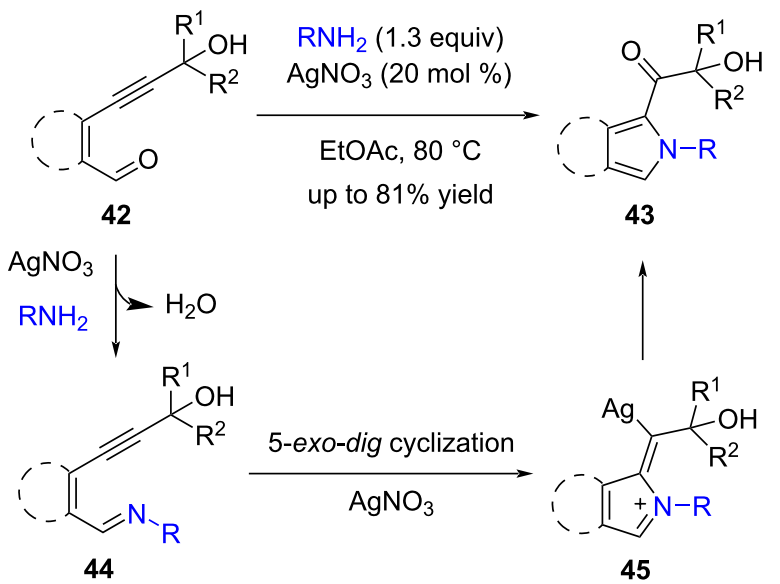

Scheme 17: Cascade cyclization of 6-hydroxyhex-2-en-4-ynals to pyrroles.

In 2017, the Reddy group also reported a method for the construction of 2-carbonylpyrroles $\mathbf{4 6}$ through $\mathrm{Au} / \mathrm{Ag}$-catalyzed intramolecular oxidative aza-annulation of 1,3-enynyl azides $\mathbf{1}$ (Scheme 18) [63]. The method is very applicable, and various aryl-substituted enynyl azides bearing electron-donating or -withdrawing (such as methyl, methoxy, chloro, cyano, nitro, acyl, and trifluoromethyl) groups all worked smoothly to 
deliver the corresponding 2-carbonylpyrroles 46 in good to excellent yield. Aliphatic enynyl azide ( $\mathrm{R}=1$-hexyl) was also tolerated efficiently under the standard conditions to afford the desired product $46 \mathbf{k}$ in $64 \%$ yield. In addition, tert-butyldimethylsilyl (TBS)-substituted enynyl azide provided the target product $\mathbf{4 6 1}$ in $34 \%$ yield.

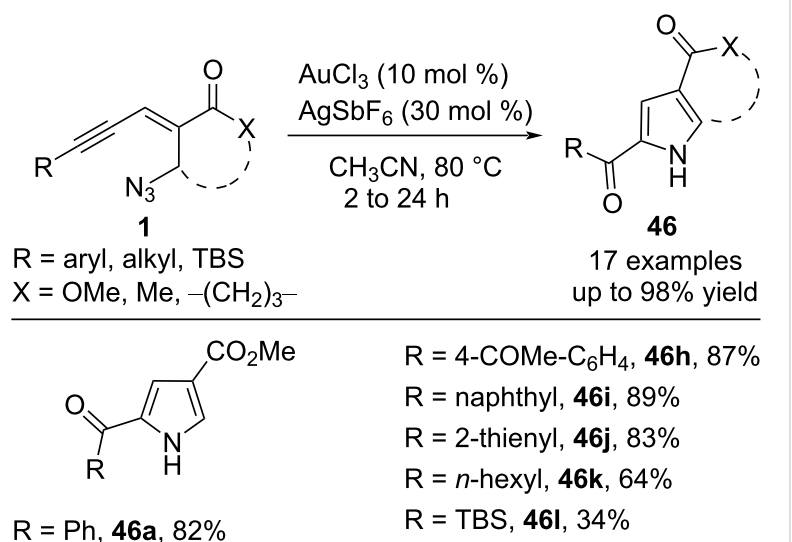

$\mathrm{R}=4-\mathrm{MeO}-\mathrm{C}_{6} \mathrm{H}_{4}, 46 \mathrm{~b}, 86 \%$

$\mathrm{R}=4-\mathrm{Me}-\mathrm{C}_{6} \mathrm{H}_{4}, 46 \mathrm{c}, 79 \%$

$\mathrm{R}=4-\mathrm{NO}_{2}-\mathrm{C}_{6} \mathrm{H}_{4}, 46 \mathrm{~d}, 84 \%$

$\mathrm{R}=4-\mathrm{CN}-\mathrm{C}_{6} \mathrm{H}_{4}, 46 \mathrm{e}, 85 \%$

$\mathrm{R}=3-\mathrm{CF}_{3}-\mathrm{C}_{6} \mathrm{H}_{4}, \mathbf{4 6 f}, 81 \%$

$\mathrm{R}=4-\mathrm{Cl}-\mathrm{C}_{6} \mathrm{H}_{4}, \mathbf{4 6 g}, 78 \%$

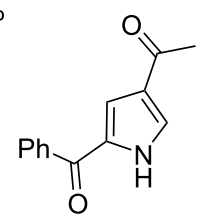

$46 \mathrm{~m}, 53 \%$

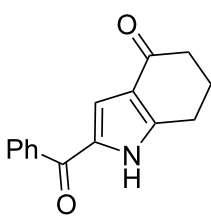

46n, $51 \%$
Scheme 18: Au/Ag-catalyzed oxidative aza-annulation of 1,3-enynyl azides.

The transformation involves a sequence of $\mathrm{C}-\mathrm{N} / \mathrm{C}-\mathrm{O}$ bond formation, and the corresponding plausible mechanism is shown in Scheme 19. Firstly, Au-coordinated alkyne undergoes regiose- lective hydration to form intermediate 48. Then, intramolecular nucleophilic attack by azide occurs to give 2-carbonyl intermediate 49. Subsequently, intermediate 49 will undergo aromatization as well as the release of a nitrogen molecule to form the desired product $\mathbf{4 6}$.

In 2018, Ding and co-workers reported the synthesis of 2-tetrazolyl-substituted 3-acylpyrroles $\mathbf{5 3}$ via sequential Ugi-azide/Agcatalyzed oxidative cycloisomerization reactions in good yield (Scheme 20) [64]. Firstly, The Ugi-azide reaction products 52 were obtained efficiently through the cascade reactions of enynals 51, primary amines, aliphatic isocyanides, and trimethylsilyl azide. The following reaction involves Ag-catalyzed intramolecular 5-endo-dig cyclization and base (DMAP)promoted oxidative isomerization. The presence of DMAP is necessary for this transformation.

Recently, copper hydride $(\mathrm{CuH})$ catalysis has been a wonderful procedure for olefin hydrofunctionalization via the formation of nucleophilic alkylcopper intermediate. In 2016, Buchwald and co-workers described a CuH-catalyzed asymmetric addition of olefin to ketones [65]. Then, they also reported another $\mathrm{CuH}-$ catalyzed coupling reaction of 1,3-enynes $\mathbf{5 4}$ and nitrile to prepare polysubstituted pyrroles $\mathbf{5 5}$ (Scheme 21) [66]. The substrates $\mathbf{5 4}$ could be easily prepared by Sonogashira coupling of terminal alkynes and vinyl halides. It is worth mentioning that the addition of the bisphosphine ligand DTBM-SEGPHOS (56) was very important to promote the transformation efficiently. The reaction showed a broad substrate scope, with aromatic and aliphatic substrates $54\left(\mathrm{R}^{1}=\right.$ aryl, heterocycle, and alkyl) being good coupling partners, providing the corresponding 2,3dialkyl-5-aryl-substituted pyrroles $\mathbf{5 5}$ in moderate to good yield. In addition, the method could tolerate a wide range of func-

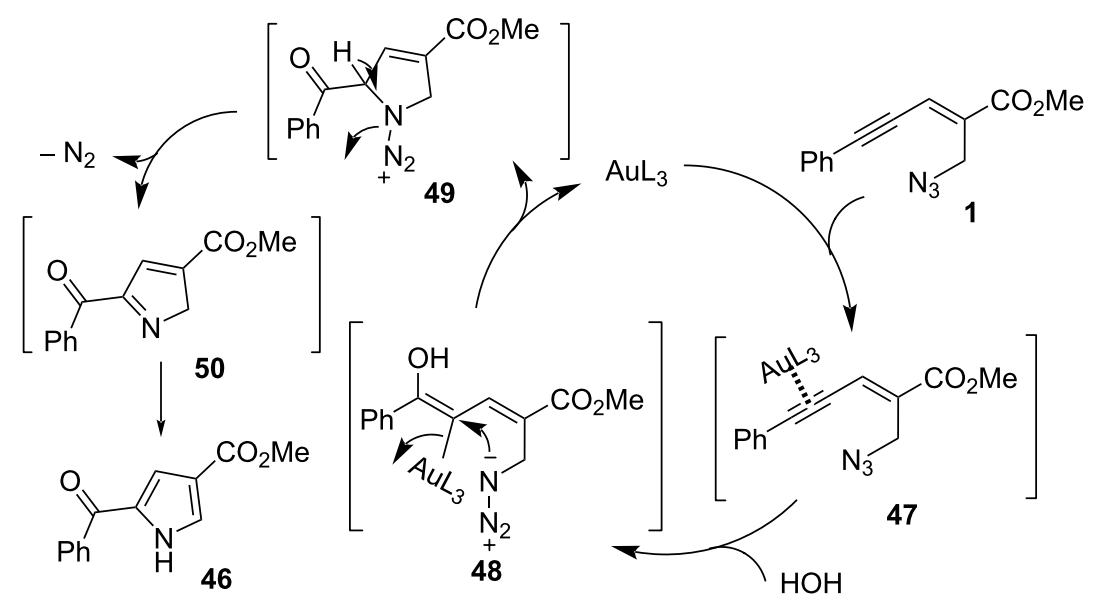



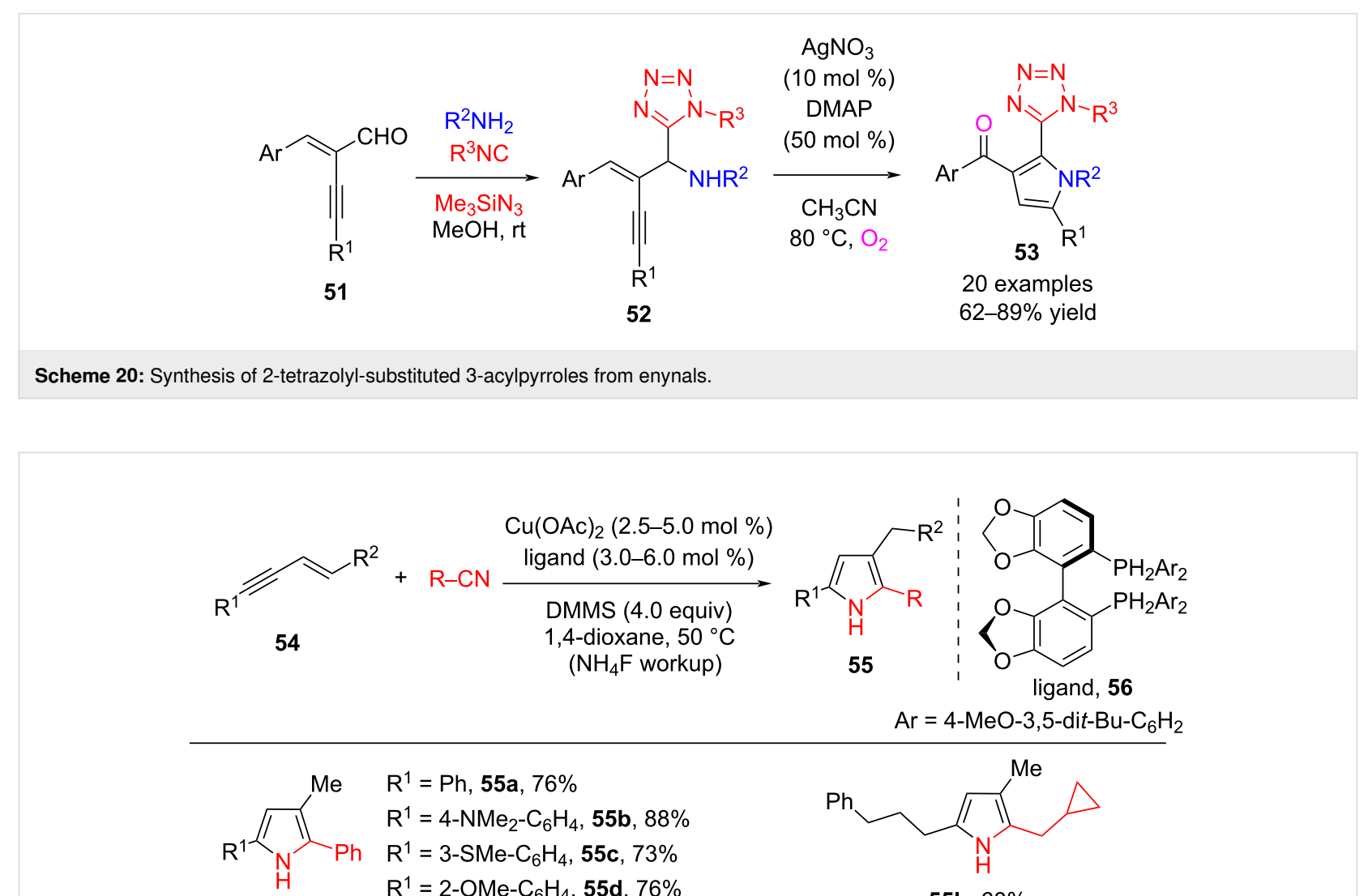

$$
\begin{aligned}
& R^{1}=\mathrm{Ph}, \mathbf{5 5 a}, 76 \% \\
& \mathrm{R}^{1}=4-\mathrm{NMe}_{2}-\mathrm{C}_{6} \mathrm{H}_{4}, \mathbf{5 5 b}, 88 \% \\
& \mathrm{R}^{1}=3-\mathrm{SMe}^{-} \mathrm{C}_{6} \mathrm{H}_{4}, \mathbf{5 5 c}, 73 \% \\
& \mathrm{R}^{1}=2-\mathrm{OMe}^{-} \mathrm{C}_{6} \mathrm{H}_{4}, \mathbf{5 5 d}, 76 \%
\end{aligned}
$$

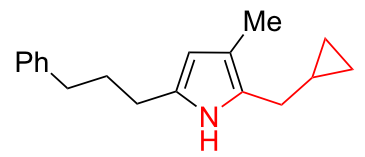

$55 \mathrm{~h}, 68 \%$
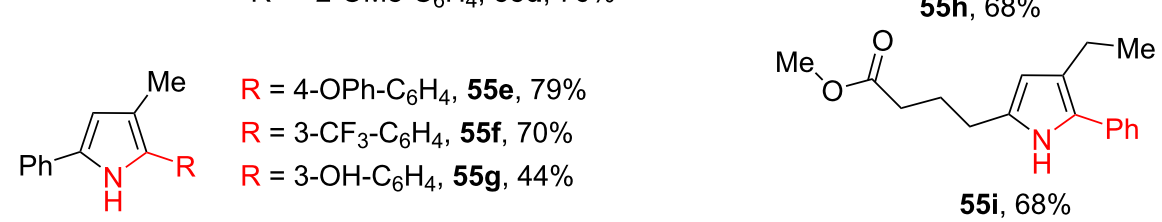

$55 i, 68 \%$

Scheme 21: CuH-catalyzed coupling reaction of 1,3-enynes and nitriles to pyrroles.

tional groups, such as phenolic hydroxy, aryl bromide, ester, terminal olefin, aryl chloride, and silyl-protected alcohol moieties. Furthermore, both aromatic and aliphatic nitriles performed well in the reaction with 1,3-enynes $\mathbf{5 4}$, providing moderate yield and regioselectivity. The $\mathrm{CuH}$-catalyzed intramolecular coupling of enyne containing a nitrile group worked smoothly and gave a moderate yield under standard conditions at a decreased concentration.

A plausible mechanism according to previously reported methods is proposed in Scheme 22. Firstly, the hydrocupration of enyne 54 with LCuH 57 provides propargylcopper intermediate $\mathbf{5 8}$. The 1,3-isomerization of $\mathbf{5 8}$ and the following nitrile addition produces imine intermediate $\mathbf{6 0}$, which subsequently undergoes intramolecular cyclization, a 1,5-hydrogen shift and $\sigma$-bond metathesis with hydrosilane to give the silylated pyrrole product 63 and the $\mathrm{LCuH}$ catalyst 57 . In addition, the intermediate $\mathbf{5 8}$ might go through isomerization to form imine intermedi- ate 64, which undergoes intramolecular cyclization to provide the minor regioisomer 67 (inner cycle in Scheme 22).

\section{Conclusion}

1,3-Enynes, one of the most significant classes of Michael acceptors for the construction of N-heterocycles, have been widely used in organic synthesis. We herein reviewed the recent advances in the development of tandem cyclization reactions of 1,3-enynes in the presence of electrophiles or Lewis acid catalysts to form pyridines and pyrroles. Series of iodinated, aminated, selenylated, sulfenylated, esterified, and hydroxylated pyridine derivatives have been prepared based on 1,3-enynes. In addition, we also reviewed the tandem cyclization of 1,3-enynes to realize various functionalizations of pyrrole derivatives, such as iodination, bromination, trifluoromethylation, azidation, carbonylation, arylation, and alkylation. The proposed mechanism generally involves two kinds of intramolecular cyclizations: one is 6-endo-dig cycliza- 


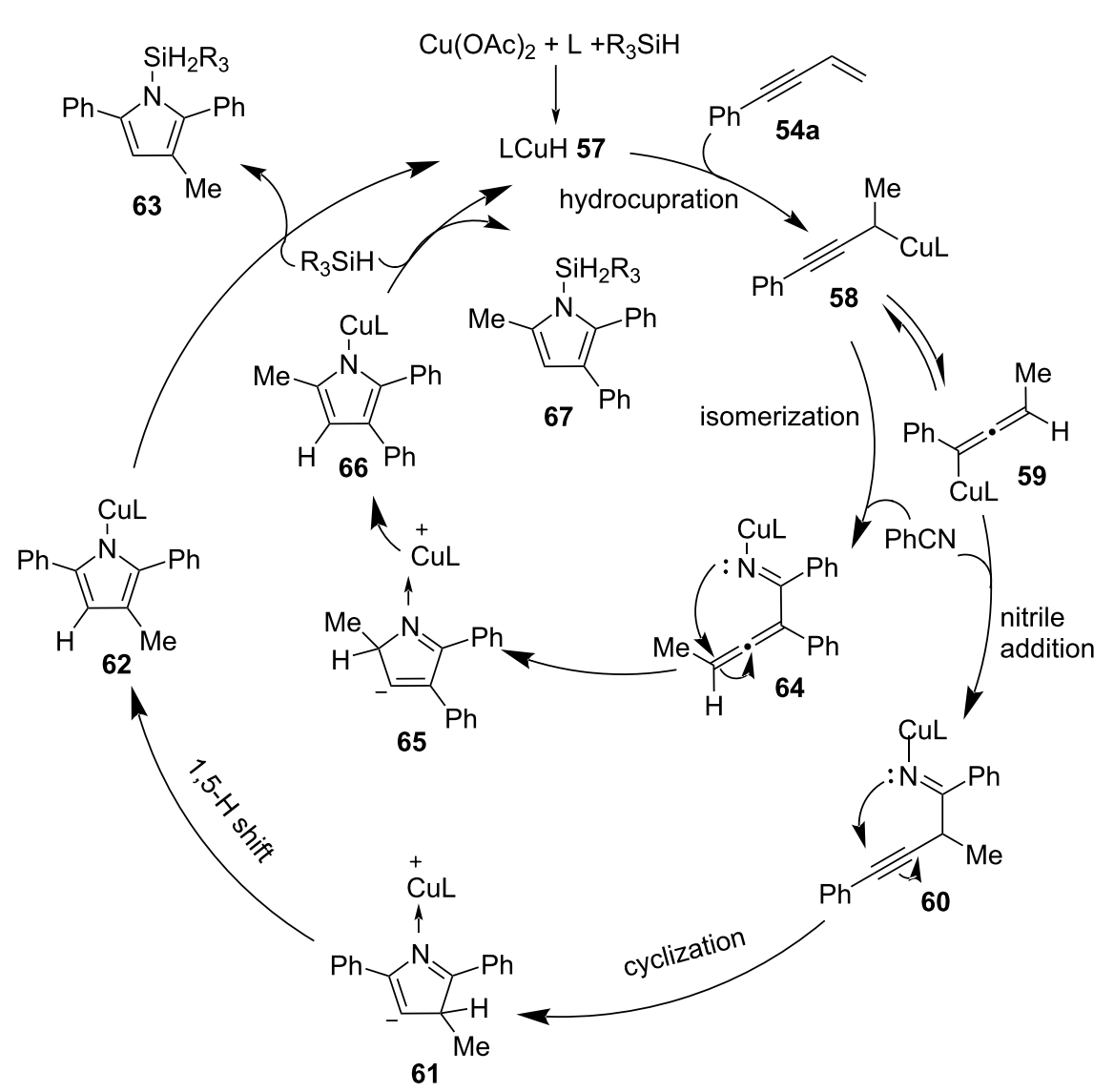

Scheme 22: The mechanism of $\mathrm{CuH}$-catalyzed coupling of 1,3-enynes and nitriles to pyrroles.

tion to promote the formation of pyridine ring derivatives and the other is 5-exo-dig cyclization to afford the pyrrole derivatives.

Considering the good biological activities and the wide applicability in synthetic organic chemistry, biopharmaceuticals, and materials, it is desirable to develop more efficient methods for the synthesis of diverse functionalized pyridine and pyrrole derivatives from easily available 1,3-enynes. Therefore, the significant challenges will focus on the following aspects in the future: i) development of more functionalizations of pyridines and pyrroles (such as fluorination, trifluoromethylthiolation, olefination, alkynylation, boronization, phosphorization, etc); ii) discovery of new transformations of 1,3-enynes to other $\mathrm{N}$-heterocycles; and iii) more extensive investigations into the mechanism.

\section{Funding}

We thank the National Natural Science Foundation of China (21961016) and the Natural Science Foundation of Jiangxi Province of China (20202BAB203003) very much for financial support.

\section{ORCID ${ }^{\circledR}$ iDs}

Yang Fu - https://orcid.org/0000-0003-0504-4419

\section{References}

1. O'Hagan, D. Nat. Prod. Rep. 2000, 17, 435-446. doi:10.1039/a707613d

2. Narendar, P.; Parthiban, J.; Anbalagan, N.; Gunasekaran, V.; Leonard, J. T. Biol. Pharm. Bull. 2003, 26, 182-187. doi:10.1248/bpb.26.182

3. Bagley, M. C.; Dale, J. W.; Merritt, E. A.; Xiong, X. Chem. Rev. 2005, 105, 685-714. doi:10.1021/cr0300441

4. Metobo, S. E.; Jin, H.; Tsiang, M.; Kim, C. U. Bioorg. Med. Chem. Lett. 2006, 16, 3985-3988. doi:10.1016/j.bmcl.2006.05.018

5. Kishbaugh, T. L. S. Curr. Top. Med. Chem. 2016, 16, 3274-3302. doi:10.2174/1568026616666160506145141

6. Gibson, V. C.; Redshaw, C.; Solan, G. A. Chem. Rev. 2007, 107, 1745-1776. doi:10.1021/cr068437y

7. Peloquin, D. M.; Schmedake, T. A. Coord. Chem. Rev. 2016, 323, 107-119. doi:10.1016/j.ccr.2016.02.005

8. Rajput, A.; Mukherjee, R. Coord. Chem. Rev. 2013, 257, 350-368. doi:10.1016/j.ccr.2012.03.024

9. Ding, Q.; Ye, S.; Cheng, G.; Wang, P.; Farmer, M. E.; Yu, J.-Q. J. Am. Chem. Soc. 2017, 139, 417-425. doi:10.1021/jacs.6b11097 10. Liu, J.; Ding, Q.; Fang, W.; Wu, W.; Zhang, Y.; Peng, Y. J. Org. Chem. 2018, 83, 13211-13216. doi:10.1021/acs.joc.8b01933 
11. Wei, Y.; Yoshikai, N. J. Am. Chem. Soc. 2013, 135, 3756-3759. doi:10.1021/ja312346s

12. Michlik, S.; Kempe, R. Angew. Chem., Int. Ed. 2013, 52, 6326-6329. doi:10.1002/anie.201301919

13. Loy, N. S. Y.; Singh, A.; Xu, X.; Park, C.-M. Angew. Chem., Int. Ed. 2013, 52, 2212-2216. doi:10.1002/anie.201209301

14. Yamamoto, S.-i.; Okamoto, K.; Murakoso, M.; Kuninobu, Y.; Takai, K. Org. Lett. 2012, 14, 3182-3185. doi:10.1021/ol301273j

15. Xu, F.; Wang, C.; Wang, D.; Li, X.; Wan, B. Chem. - Eur. J. 2013, 19, 2252-2255. doi:10.1002/chem.201203909

16. Martin, R. M.; Bergman, R. G.; Ellman, J. A. J. Org. Chem. 2012, 77, 2501-2507. doi:10.1021/jo202280e

17. Wang, C.; Li, X.; Wu, F.; Wan, B. Angew. Chem., Int. Ed. 2011, 50, 7162-7166. doi:10.1002/anie.201102001

18. D'Souza, B. R.; Lane, T. K.; Louie, J. Org. Lett. 2011, 13, 2936-2939. doi:10.1021/ol2009939

19. Hyster, T. K.; Rovis, T. Chem. Commun. 2011, 47, 11846-11848. doi:10.1039/c1cc15248c

20. Reyes, J. C. P.; Romo, D. Angew. Chem., Int. Ed. 2012, 51, 6870-6873. doi:10.1002/anie.201200959

21. Fan, H.; Peng, J.; Hamann, M. T.; Hu, J.-F. Chem. Rev. 2008, 108, 264-287. doi:10.1021/cr078199m

22. Khajuria, R.; Dham, S.; Kapoor, K. K. RSC Adv. 2016, 6, 37039-37066. doi:10.1039/c6ra03411j

23. Bhardwaj, V.; Gumber, D.; Abbot, V.; Dhiman, S.; Sharma, P. RSC Adv. 2015, 5, 15233-15266. doi:10.1039/c4ra15710a

24. Jung, E.-K.; Leung, E.; Barker, D. Bioorg. Med. Chem. Lett. 2016, 26 , 3001-3005. doi:10.1016/j.bmcl.2016.05.026

25. Lucas, X.; Wohlwend, D.; Hügle, M.; Schmidtkunz, K.; Gerhardt, S.; Schüle, R.; Jung, M.; Einsle, O.; Günther, S. Angew. Chem., Int. Ed. 2013, 52, 14055-14059. doi:10.1002/anie.201307652

26. Young, I. S.; Thornton, P. D.; Thompson, A. Nat. Prod. Rep. 2010, 27, 1801-1839. doi:10.1039/c0np00014k

27. Walsh, C. T.; Garneau-Tsodikova, S.; Howard-Jones, A. R. Nat. Prod. Rep. 2006, 23, 517-531. doi:10.1039/b605245m

28. Ren, Y.; Jiao, X.; Zhang, L. Saudi J. Biol. Sci. 2018, 25, 469-473. doi:10.1016/j.sjbs.2017.11.043

29. Wójcicka, A.; Redzicka, A. Pharmaceuticals 2021, 14, 354 doi:10.3390/ph14040354

30. Estévez, V.; Villacampa, M.; Menéndez, J. C. Chem. Soc. Rev. 2014, 43, 4633-4657. doi:10.1039/c3cs60015g

31. Estévez, V.; Villacampa, M.; Menéndez, J. C. Chem. Soc. Rev. 2010, 39, 4402-4421. doi:10.1039/b917644f

32. Xu, X.; Chen, J.; Ke, J.; Zhang, K.; Wu, P.; Wang, S. Chin. J. Org. Chem. 2021, 41, 206-228. doi:10.6023/cjoc202005018

33. Menéndez, J.; Leonardi, M.; Estévez, V.; Villacampa, M. Synthesis 2019, 51, 816-828. doi:10.1055/s-0037-1610320

34. Balakrishna, A.; Aguiar, A.; Sobral, P. J. M.; Wani, M. Y.; Almeida e Silva, J.; Sobral, A. J. F. N. Catal. Rev.: Sci. Eng. 2019, 61, 84-110. doi:10.1080/01614940.2018.1529932

35. Gulevich, A. V.; Dudnik, A. S.; Chernyak, N.; Gevorgyan, V. Chem. Rev. 2013, 113, 3084-3213. doi:10.1021/cr300333u

36. Nakamura, I.; Yamamoto, Y. Chem. Rev. 2004, 104, 2127-2198. doi:10.1021/cr020095i

37. Yoshikai, N.; Wei, Y. Asian J. Org. Chem. 2013, 2, 466-478. doi:10.1002/ajoc.201300016

38. Kawakita, K.; Beaumier, E. P.; Kakiuchi, Y.; Tsurugi, H.; Tonks, I. A.; Mashima, K. J. Am. Chem. Soc. 2019, 141, 4194-4198. doi:10.1021/jacs.8b13390
39. Li, M.-B.; Grape, E. S.; Bäckvall, J.-E. ACS Catal. 2019, 9, 5184-5190. doi:10.1021/acscatal.9b01041

40. Wang, P.; Xiao, J.; Leng, X.; Deng, L. Chin. J. Org. Chem. 2019, 39, 2243-2250. doi:10.6023/cjoc201904040

41. Bläsing, K.; Bresien, J.; Labbow, R.; Michalik, D.; Schulz, A.; Thomas, M.; Villinger, A. Angew. Chem., Int. Ed. 2019, 58, 6540-6544. doi:10.1002/anie.201902226

42. Anker, M. D.; Lein, M.; Coles, M. P. Chem. Sci. 2019, 10, 1212-1218. doi:10.1039/c8sc04078h

43. Song, X.-R.; Qiu, Y.-F.; Liu, X.-Y.; Liang, Y.-M. Org. Biomol. Chem. 2016, 14, 11317-11331. doi:10.1039/c6ob01965j

44. Rostovtsev, V. V.; Green, L. G.; Fokin, V. V.; Sharpless, K. B. Angew. Chem., Int. Ed. 2002, 41, 2596-2599. doi:10.1002/1521-3773(20020715)41:14<2596::aid-anie2596>3.0.co;24

45. Kolb, H. C.; Finn, M. G.; Sharpless, K. B. Angew. Chem., Int. Ed. 2001, 40, 2004-2021. doi:10.1002/1521-3773(20010601)40:11<2004::aid-anie2004>3.0.co;25

46. Dherbassy, Q.; Manna, S.; Talbot, F. J. T.; Prasitwatcharakorn, W.; Perry, G. J. P.; Procter, D. J. Chem. Sci. 2020, 11, 11380-11393. doi:10.1039/d0sc04012f

47. Bao, X.; Ren, J.; Yang, Y.; Ye, X.; Wang, B.; Wang, H. Org. Biomol. Chem. 2020, 18, 7977-7986. doi:10.1039/d0ob01614d

48. Fu, L.; Greßies, S.; Chen, P.; Liu, G. Chin. J. Chem. 2020, 38, 91-100. doi:10.1002/cjoc.201900277

49. Raji Reddy, C.; Panda, S. A.; Reddy, M. D. Org. Lett. 2015, 17, 896-899. doi:10.1021/ol503752k

50. Reddy, C. R.; Prajapti, S. K.; Ranjan, R. Org. Lett. 2018, 20, 3128-3131. doi:10.1021/acs.orglett.8b01228

51. Reddy, C. R.; Ranjan, R.; Prajapti, S. K. Org. Lett. 2019, 21, 623-626. doi:10.1021/acs.orglett.8b03695

52. Chun, Y. S.; Lee, J. H.; Kim, J. H.; Ko, Y. O.; Lee, S.-g. Org. Lett. 2011, 13, 6390-6393. doi:10.1021/ol202691b

53. Barday, M.; Ho, K. Y. T.; Halsall, C. T.; Aïssa, C. Org. Lett. 2016, 18, 1756-1759. doi:10.1021/acs.orglett.6b00451

54. Sajid, M. A.; Khan, Z. A.; Shahzad, S. A.; Naqvi, S. A. R.; Usman, M. Mol. Diversity 2020, 24, 295-317. doi:10.1007/s11030-019-09930-x

55. Bharathiraja, G.; Sakthivel, S.; Sengoden, M.; Punniyamurthy, T. Org. Lett. 2013, 15, 4996-4999. doi:10.1021/ol402305b

56. Zhou, X.; Huang, C.; Zeng, Y.; Xiong, J.; Xiao, Y.; Zhang, J. Chem. Commun. 2017, 53, 1084-1087. doi:10.1039/c6cc09595j

57. Huang, C.; Zeng, Y.; Cheng, H.; Hu, A.; Liu, L.; Xiao, Y.; Zhang, J. Org. Lett. 2017, 19, 4968-4971. doi:10.1021/acs.orglett.7b02427

58. Bharathiraja, G.; Sengoden, M.; Kannan, M.; Punniyamurthy, T. Org. Biomol. Chem. 2015, 13, 2786-2792. doi:10.1039/c4ob02508c

59. Li, Y.; Lu, Y.; Quu, G.; Ding, Q. Org. Lett. 2014, 16, 4240-4243. doi:10.1021/ol501939m

60. Ge, J.; Ding, Q.; Wang, X.; Peng, Y. J. Org. Chem. 2020, 85, 7658-7665. doi:10.1021/acs.joc.9b03470

61. Ge, J.; Ding, Q.; Yang, M.; He, T.; Peng, Y. Org. Biomol. Chem. 2020, 18, 8908-8915. doi:10.1039/d0ob01927e

62. Gandhi, S.; Baire, B. ChemistrySelect 2017, 2, 3964-3968. doi:10.1002/slct.201700514

63. Reddy, C. R.; Panda, S. A.; Ramaraju, A. J. Org. Chem. 2017, 82, 944-949. doi:10.1021/acs.joc.6b02468

64. Kong, H.-H.; Pan, H.-L.; Ding, M.-W. J. Org. Chem. 2018, 83, 12921-12930. doi:10.1021/acs.joc.8b01984

65. Yang, Y.; Perry, I. B.; Lu, G.; Liu, P.; Buchwald, S. L. Science 2016, 353, 144-150. doi:10.1126/science.aaf7720 
66. Zhou, Y.; Zhou, L.; Jesikiewicz, L. T.; Liu, P.; Buchwald, S. L.

J. Am. Chem. Soc. 2020, 142, 9908-9914. doi:10.1021/jacs.0c03859

\section{License and Terms}

This is an Open Access article under the terms of the Creative Commons Attribution License

(https://creativecommons.org/licenses/by/4.0). Please note that the reuse, redistribution and reproduction in particular requires that the author(s) and source are credited and that individual graphics may be subject to special legal provisions.

The license is subject to the Beilstein Journal of Organic Chemistry terms and conditions:

(https://www.beilstein-journals.org/bjoc/terms)

The definitive version of this article is the electronic one which can be found at:

https://doi.org/10.3762/bjoc.17.163 